\title{
The Blue Marble: An Essay on the Commonality of Human Experience
}

\author{
Alenka Suhadolnik
}

The following essay consists of three sections, which respectively borrow the titles of one magazine, one exhibition and one novel. This text is a short reflection into the universality of the human experience and the tasks that face the global community. I believe the arts have a crucial role in revealing this, which I hope to showcase through the three aforementioned cultural pieces.

\section{The Whole Earth}

In the fall of 1968, the first volume of an American counterculture magazine, Whole Earth Catalog, published one of the first photographs of the earth from outer space in color: a blue and white alabaster ball on a black background. This iconic image later became known as the "blue marble."

The magazine featured product reviews as well as essays and articles, focusing on ecology, self-sufficiency, DIY projects and holism. Through these contributions, it succeeded in forging alliances between traditionally opposing social groups. Namely, between the military responsible for the space program and the nascent ecological movement, as well as the emerging fields of computer science cybernetics and informatics. Steve Jobs has even compared the Whole Earth Catalog to Google, saying that it was "one of the bibles of (his) generation." He added: "It was sort of like Google in paperback form, 35 years before Google came along. It was idealistic and overflowing with neat tools and great notions."

The "Blue Marble" thus became an iconic image for the next few decades and a powerful visual articulation of the commonality and universality of the human experience. An image of our planet that redefined the world as we knew it, because we

\footnotetext{
A. Suhadolnik $(\bowtie)$

Embassy of the Republic of Slovenia to the People's Republic of China, Beijing, China
} 
could see the world from the outside, without borders, without centers or peripheries; we no longer saw the land we stood on, but a planet among the planets.

The whole earth, finite in its resources, is the only one we have, and it belongs to all of us. Utopian universalism was inscribed into this image of the whole earth, which became the catalyst for the ecological movement and a reminder of the human condition.

\section{The Family of Man}

First curated in 1955, in the wake of World War II, The Family of Man is hailed as the most successful photography exhibition ever assembled (Azoulay 2013; Latour 2018). 503 pictures from 68 countries by 273 artists adorned the walls of the Museum of Modern Art (MoMA) in New York City from January to May. Spearheaded by photographer, painter and curator Edward Steichen; the exhibition was published in a catalog of the same name, which reproduced all 503 photographs. Since its publication, it has sold over four million copies and has been continuously in print. The exhibition toured the world for eight years, attracting more than nine million visitors.

The aim of the exhibition was to showcase the commonality of human experience though the common language of photography, attempting to answer two fundamental questions on the human condition: "What is humanity?" and "What does humanity have in common?"

The exhibit and publication have been subject to various interpretations and critiques. The exhibition has faced backlash for propagating American values, disguised as universal values, under the watchful gaze of Uncle Sam. It has also been criticized for being too sentimental, derivative, ideological and culturally colonial. Despite this, The Family of Man remains the most visited photography exhibition of all time. As Ariela Azoulayart curator, author and filmmaker-explains the exhibition audience understood the universal message of the artwork, whether they liked the photographs or not. Azoulay presents the exhibition not only as an important milestone in the history of photography but also as a "seminal event in the history of the relationship between photography and human rights" and also as "the visual proxy of the UN Universal Declaration of Human Rights."

The photographs in the exhibition were comprised of 37 sections: birth, marriage, children, work, relationships, learning, death, aloneness and compassion being among them. The exhibition has, by juxtaposing photographs of the same situation, succeeded in establishing a universal visual discourse.

In the here and now, the world is battling a global pandemic, which is equally heavily documented though photographs, articles and social media posts. Our collective universal experience is established through the commonality of fear. The fear of getting sick, of getting others sick, of losing our dignity, of our loneliness, of the future and what the future brings. A universal experience now no longer requires 
an outside perspective: we simply need to look at ourselves and our smartphones in order to understand what the rest of the world is going through.

COVID-19 is not the first pandemic of the modern age. The Spanish flu is also an example of a fairly recent global pandemic, which affected the world from 1918 to 1920 and nearly decimated Europe. 500 million people fell ill and at least 40 million died from the illness. These numbers were higher than the casualties of the First World War. Because the illness erupted at a time when WWI was just ending, historians were ill equipped to address the pandemic to the point one would expect, considering the extraordinarily high casualties.

Because of our technologically connected, globalized world, the pandemic of our time is nothing like the Spanish flu. While we could initially hope that the pandemic would be contained within certain regions, the virus quickly spread between countries and continents. The world went into lockdown and began practicing social distancing. While everyone else quarantined in their homes, scientists retreated into their labs in order to come up with a vaccine that could prevent patients from getting the virus, which they discovered surprisingly quickly. Thanks to technological advancements and Internet access, new social interactions and bonds were formed, through school, work, cooking classes, workshops, music lessons and much more on Zoom: all transferred from real life to the virtual world.

COVID-19 affected all of us, regardless of where we were from or where we lived.

\section{The Ministry for the Future}

The Ministry for the Future is a novel written by American author Kim Stanley Robinson in 2020 and belongs to the novel genre of climate fiction, which deals with the consequences of climate change in the world as we know it or in the near future, as opposed to science fiction, which most often deals with apocalyptic worlds out of our realm of reality.

Robinson's novel combines fictional eyewitness accounts on global warming with non-fictional excerpts on climate change-the main question of our time. The protagonist of the novel is Mary Murphy, the former foreign minister of Ireland, who is leading a new climate institution under the Paris Climate Agreement. The mission of this institution, soon after named "The Ministry for the Future," is to defend the rights of posterity, which have the same validity as the rights of the present generation.

The story follows Ms. Murphy as she manages to convince the central banks that the stability of their currencies and the international financial system is in danger because of the climate crisis. Despite the powerful vested interests of both countries and industries, she finds her answers in a coordinated global round of green quantitative easing through a new complementary crypto currency: Carbon Coin. Since central banks are bound to long-term purchase, Carbon Coin becomes the safest investment and the global economic system becomes motivated to fight against global warming. 
When doing research for his book, Robinson kept coming back to diplomacy, international organizations, central banks, regulation of the international financial system, and rule of law, as essential tools for tackling climate change.

Much like Ms. Murphy, we are also taking strides toward international climate diplomacy, which are marked by two climate summits this year. Namely, the UN Climate Change Conference (COP26) in Glasgow and the UN Biodiversity Conference (COP15) in Kunming. 2021 is, therefore, a fundamental year for collective global action. While we work on containing a worldwide health crisis and restarting the global economy, many countries are recognizing it is time we develop and accomplish tangible environmental missions, since climate change is already showing its dire consequences. With increased sea levels, melting ice caps and extreme weather events such as floods, drought, loss of biodiversity and wildfires, the next ten years are crucial.

\section{The Coronavirus as a Lesson for All Crises}

The Coronavirus pandemic has shed additional light on the climate crisis, which according to climatologists is the tragedy of the time horizon, while the pandemic is a tragedy that is happening here and now. Nevertheless, both are equally unprecedented and require our immediate attention.

What lessons can we learn from this pandemic? And which can we use to tackle climate change?

The Coronavirus crisis has put global public health at the forefront of challenges that are facing humanity. The necessity of a robust public health system and health as a global public good have been put in focus. But we now understand that global public health is not just a matter of national health systems and international health organizations, but also a matter of academia, non-governmental and philanthropic organizations, healthcare workers, as well as individual healthcare activists and advocates. The same sort of activism and building of alliances is needed in order to preserve biodiversity and combat global warming.

In 2021, we understand that fast, massive behavioral change is possible. We now know that we can adapt, because we've seen ourselves adapt through our own eyes, through our own experiences. We saw ourselves, as well as our friends and family, stay home in order to protect those who are more vulnerable and more susceptible to complications due to the Coronavirus. We self-isolated today so that we could spend time together tomorrow. We know we can implement and carry out lasting, systemic changes in behavior in order to protect others. Not just in today's generation but also in future ones.

This present health crisis has once again shown that all crises increase inequality. COVID-19 has upended all aspects of our lives. And while we are equal in a commonality of fear, we are also becoming more unequal in other aspects within and between countries. We are not equal in terms of vaccine accessibility, the nature of our work, the social care systems that allow for the needed support of the most vulnerable, nor 
are we equal in the possibilities of a prompt economic recovery. Women, who globally represent $70 \%$ of the employees in the informal sector, are especially burdened.

According to philosopher Dr. Bruno Latour, "everyone now knows that the climate question is at the heart of all geopolitical issues and that it is directly tied to questions of injustice and inequality." With an untamed climate crisis, the inequalities would be much bigger and more disruptive.

A global pandemic is also a time to globally rethink how our society works. Hasn't visionary systemic change always occurred during or after major crises or wars? This occurred with the formation of the United Nations in the wake of the Second World War, aiming to prevent future wars. Later on, in 1948, the Universal Declaration of Human Right was adopted.

Agreements on climate change mitigation and adaptation are already becoming part of a global social contract. The right to a healthy environment is gaining recognition at national and regional levels. It has acquired constitutional recognition and protection in 110 states, while over 120 states have ratified regional treaties that explicitly include the right to a healthy environment. The formal recognition by the United Nations of the human right to a safe, clean, healthy and sustainable environment would be an important step forward. Much needs to be done in this year, and in the crucial next decade, in order to tame climate change.

This unprecedented health crisis has allowed us to recognize that the burden of a global catastrophe needs to be more equally distributed between individuals, businesses and governments. Because of this, governments are unveiling the biggest stimulus packages in history for economic recovery and supporting their citizens who lost their jobs, their businesses and their homes. The role of governments in tackling the crisis caused by the Coronavirus pandemic is widely recognized. For example, the European Union has adopted the Next Generation EU COVID-19 stimulus package, a EUR 750 billion temporary instrument, which will help repair the social and economic damage caused by the COVID-19 pandemic. Together with the EU's long-term budget, the Next Generation EU will be the largest stimulus package ever financed through the EU. The aim of this sizable stimulus is to build a greener, more digital and more resilient Europe.

In 2020, we learned that investments in science and research can change the world, as we have witnessed in the race for the COVID-19 vaccine, which is by far the largest public health operation in history. If the global community would apply the same vigor, and invest in research and innovation addressing climate change, we could expect the same results on climate health.

We have also discovered that questions of health and environment are inextricably linked. When the pandemic first began, health professionals began to advise the public to wash their hands at least six to ten times a day. And in order to wash your hands, you need water. In 2010, the United Nations General Assembly endorsed the human right to water and sanitation and acknowledged that clean drinking water and sanitation are essential to the realization of all human rights. Never before have we better understood the meaning of WASH (water, sanitation and hygiene) as we do today. 


\section{Water as a Right and Mechanism for Peace}

Water is set to become a strategic asset of the twenty-first century and one of the most important global challenges we face. $40 \%$ of the world's population is already affected by water scarcity, while water demand is set to rise more than $50 \%$ by 2030 . Over 2.1 billion people worldwide suffer from not having adequate water access, while 2.3 billion (meaning, approximately $30 \%$ of the world's population) do not have access to improved sanitation.

Allow me to briefly introduce my country's stance and ambitions on the issue of water. Slovenia is one of the most water rich European countries and the second in Europe to amend its constitution by including a right to drinking water. It has an abundance of lakes, rivers, streams and freshwater springs. This has inspired Slovenia to establish a good precedent on water and integrated water management, as well as on transboundary water cooperation on a bilateral and regional level. The understanding of water as a public good resulted in the Slovenian parliament's adoption of the 2016 amendment which declared water "a public good managed by the state" and "not a market commodity."

The importance that Slovenia puts on the issue of water is reflected in the fact that water will be one of the priorities during our Presidency of the Council of the European Union in the second half of 2021. Slovenia will be advocating for water to be systematically and comprehensively embedded across all aspects and facets of the EU's external action. Our approach is based on the triple "humanitariandevelopment-peace" nexus, essentially promoting water cooperation as a mechanism for peace, development, as well as political and social security, while emphasizing the human right to water and sanitation.

While the Coronavirus crisis changed political and environmental priorities for 2020, 2021 still brought us a certain amount of optimism. At the UN General Assembly last September, the President of China, Xi Jinping announced "a peak of carbon emissions before 2030" and pledged to "achieve carbon neutrality before 2060." President Xi emphasized: "COVID-19 reminds us that humankind should launch a green revolution." Meanwhile, the United States of America has returned to the Paris Agreement and the European Union remains committed to their environmental missions and aims to become the first climate neutral continent. At the announcement of the European Green Deal, the European Commission President Ursula von der Leyen stated in a video interview: "This is Europe's man on the moon moment... Our goal is to reconcile the economy with our planet."

As much as we need measures and campaigns in order to stop the pandemic, we need measures and campaigns against climate change. In order to achieve this, we will need to build alliances: top down, bottom up and also side to side. We need inclusive, emancipatory and collective engagement in order to create a society that is safe for all. The good news is we already have the blueprints necessary for tackling climate change and are armed with knowledge from the Coronavirus pandemic. With the help of the Paris Climate Agreement and the UN Sustainable Development Goals, we can shift from climate fiction to climate action. 


\section{References}

Azoulay A (2013) The family of man - a visual universal declaration of human rights. In: Keenan T, Zolgahdr T (eds) The human snapshot. Sternberg Press, Berlin, pp 19-48

Keber K, Španska gripa, pandemija moderne dobe. https://www.alternator.science/en/shorter/spa nska-gripa-pandemija-moderne-dobe/

Latour B (2018) Down to earth: politics in the new climatic regime, polity. Kim Stanley ROBINSON, The ministry for the future: a novel, Orbit, 2020

https://www.rollingstone.com/culture/culture-features/the-ministry-for-the-future-interview-kimstanley-robinson-1101738/

https://news.stanford.edu/2005/06/14/jobs-061505/

https://undocs.org/en/A/75/PV.4

https://www.theparliamentmagazine.eu/news/article/europes-man-on-the-moon-moment-von-derleyen-unveils-eu-green-deal

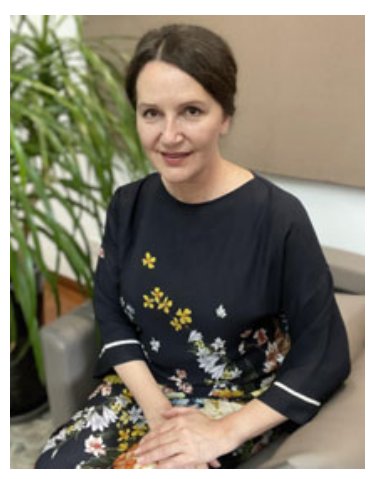

H.E. Ms. Alenka Suhadolnik is the ambassador of the Republic of Slovenia to the People's Republic of China. She has been the ambassador of Slovenia to China since 2019. After receiving her Master in Economics, Ms. Suhadolnik joined the Slovenian Ministry of Foreign Affairs. She also served as Consul General of the Republic of Slovenia in New York (2004-2008), and as ambassador of the Republic of Slovenia to the State of Israel (2011-2015). Ms. Suhadolnik played an important role in developing several Slovenian international development cooperation institutions. She also served as a member of International Trade Promotion Commission, SID Bank - Slovenian Export and Development Bank (2017-2019).

Open Access This chapter is licensed under the terms of the Creative Commons AttributionNonCommercial-NoDerivatives 4.0 International License (http://creativecommons.org/licenses/bync-nd/4.0/), which permits any noncommercial use, sharing, distribution and reproduction in any medium or format, as long as you give appropriate credit to the original author(s) and the source, provide a link to the Creative Commons license and indicate if you modified the licensed material. You do not have permission under this license to share adapted material derived from this chapter or parts of it.

The images or other third party material in this chapter are included in the chapter's Creative Commons license, unless indicated otherwise in a credit line to the material. If material is not included in the chapter's Creative Commons license and your intended use is not permitted by statutory regulation or exceeds the permitted use, you will need to obtain permission directly from the copyright holder.

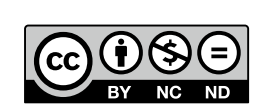

